\title{
Cerebellar anaplastic astrocytoma in adult patients: 15 consecutive cases from a single institution and literature review
}

Artem Belyaev ${ }^{1}$, Dmitry Usachev${ }^{1}$, Marina Ryzhova ${ }^{1}$, Gleb Gulida ${ }^{1}$, Vasilisa Skvortsova ${ }^{2,3}$, Igor Pronin ${ }^{1}$, Grigory Kobiakov${ }^{1}$.

\author{
${ }^{1}$ Burdenko Neurosurgery Center, $4^{\text {th }}$ Tverskaya-Yamskaya, 16, Moscow, 125047, Russia \\ ${ }^{2}$ Wellcome Trust Centre for Neuroimaging, University College London, London, \\ United Kingdom; \\ ${ }^{3}$ Max Planck University College London Centre for Computational \\ Psychiatry and Ageing Research, London, United Kingdom;
}

\begin{abstract}
Adult cerebellar anaplastic astrocytomas (cAA) are rare entities and their clinical and genetic appearances are still ill defined. Previously, malignant gliomas of the cerebellum were combined and reviewed together (cAA and cerebellar glioblastomas (cGB), that could have possibly affected overall results. We present characteristics of 15 adult patients with cAA and compared them to a series of 45 patients with a supratentorial AA (sAA). The mean age at cAA diagnosis was 39.3 years (range 19-72). A history of neurofibromatosis type I was noted in 1 patient (6.7\%). An IDH-1 mutation was identified in 6/15 cases and a methylated MGMT promoter in 5/15 cases. Patients in study and control groups were matched in age, sex and IDH1 mutation status. Patients in a study group tended to have a more frequent multifocal presentation at diagnosis (13\% vs. $4.4 \%$ ) and were associated with longer overall survival (50 vs. 36.5 months), but the difference did not reach statistical significance. In both cAA and supratentorial AA groups presence of the IDH-1 mutation remains a positive predictor for the prolonged survival. The present study suggests that adult cAA constitute a group of gliomas with relatively high rate of IDH-1 mutations and prognosis similar to supratentorial AA. The present study is the first to systematically compare CAA and supratentorial AA with respect to their genetic characteristics and suggests that both groups shows a similar survival prognosis.
\end{abstract}

Key words: cerebellar anaplastic astrocytoma, IDH-1 mutation, MGMT methylation, multifocal glioma.

\section{Introduction}

Anaplastic astrocytomas of the cerebellum (cAA) are extremely rare entities with just a few case reports or case series published so far $[1,3,4,7,9,10,12,14,18,22-25,30,31]$. Given the relative weight of the cerebellum (approximately $10 \%$ of the brain), one could expect $10 \%$ of anaplastic astrocytomas to arise from cerebellum [16]. However, no incidence of cAA has been reported due to its' utmost scarcity. This is not surprising that literature dealing with malignant gliomas of the cerebellum mostly consists of cerebellar glioblastomas, including both pediatric and adult patients, and brainstem tumours involving cerebellum [5,8,11,15,17,21,32,34].

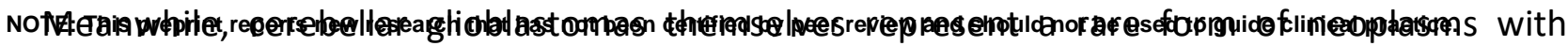
reported incidence rate of $0.24-4.1 \%$ from all primary glioblastomas [19]. Sporadic articles 
medRxiv preprint doi: https://doi.org/10.1101/2020.09.09.20188938; this version posted September 14,2020 . The copyright holder for this preprint (which was not certified by peer review) is the author/funder, who has granted medRxiv a license to display the preprint in

All rights reserved. No reuse allowed without permission.

devoted to the CAA were published decades ago and combined CGB and CAA in the analysis due to insufficient number of patients in each group. In total only 45 cases of cAAs have been documented in the literature (see Table 2). Importantly, previous studies lack any genetic characteristics of cAA and no standard therapeutic approach has been developed or advocated. Here we leverage on the unique opportunity to follow up 15 patients with cAA who received treatment at Burdenko Neurosurgery Center.

The aim of the present study was to describe genetic and clinical characteristics of 15 adult cAA patients and to compare them both qualitatively and quantitively to those of a series of patients with supratentorial anaplastic astrocytomas with an emphasis to overall survival, multifocal location and IDH-1 mutational status.

\section{Materials and methods}

The database of Burdenko Neurosurgery Center was screened from 2000 to March 2020 and a total of 15 cAA patients met our criteria: 1. AA was located in cerebellar vermis or hemispheres (patients presenting with tumours involving both brainstem and cerebellum were excluded from the study); 2. all patients were evaluated by MRI before admission and underwent maximal safe resection; 3. all patients received adjuvant (chemo- and radiotherapy) in the post-operative period. Biopsy results were reviewed by 3 independent experienced neuropathomorphologists.

A consecutive series of 45 adult patients with supratentorial hemispheric anaplastic astrocytomas not involving basal ganglia and/or midline structures were extracted from our database and used as a comparative group. Two patients in the main group presented with multiple lesions (parietal lobe in one case with unconfirmed supratentorial tumour biology and frontal lobe + corpus callosum in another case with glioblastoma histology); in the control group there were also 2 patients with multiple supratentorial AAs. All specimens - both in study and control group - were available for molecular analysis. The groups matched by patient gender, age and IDH-1 mutation status .

\section{Statistical methods}

Survival curves analyses and Cox regression models were performed using R-package (version 3.3.3 (R Core Team, 2017) with package "survival" [27,28].

For the Cox regression investigating the status of the IDH-1 across two groups we performed a regression with clustering patients within each group for the purposes of a robust variance estimation) [29]. 
medRxiv preprint doi: https://doi.org/10.1101/2020.09.09.20188938; this version posted September 14,2020 . The copyright holder for this preprint (which was not certified by peer review) is the author/funder, who has granted medRxiv a license to display the preprint in

All rights reserved. No reuse allowed without permission.

For MGMT Cox regression model one of the patients was excluded because of the missing MGMT status leaving 14 patients for the analysis.

\section{Results}

Characteristics of 15 patients with cerebellar anaplastic astrocytomas are presented in Table 3.

\section{Clinical characteristics}

The mean age at diagnosis was 39 years (range 19-72 years). There were 8 men and 7 women. $A$ personal history of neurofibromatosis type I (NF1) was noted in 1 patient (6.7\%), as well as a personal history of previous cancer (cervical cancer). Clinical manifestation consisted mostly of intracranial hypertension syndromes (nausea, vomiting) 60\% of cases and cerebellar symptoms (gait and writing disturbances) $47 \%$ of cases. One of two patients with concomitant supratentorial tumors experienced seizures.

\section{Histological and molecular characteristics}

Biopsy samples were reviewed by 3 independent neuropathomorphologists and patents were included into study group only upon consensus regarding tumour type (in accordance with WHO 2016 classification of CNS tumours). Median Ki67 labeling index was 15\% (range 8-50\%). Molecular analysis revealed that 6 patients had IDH-1 mutation; methylated MGMT-promoter was identified in 5 patients and H3F3AK27 mutation was revealed in 1 patient.

\section{Treatment and outcome}

One patient underwent tumour biopsy, in 3 patients subtotal resection (STR) was performed, and in 11 patients surgery consisted of gross-total resection (GTR) based upon surgeon's impression. In one patient repeated surgery was performed in 12 months' time due to tumour recurrence (no adjuvant treatment was conducted in-between). Notably, the first surgery consisted of GTR, however during the second one only STR was achieved because of brainstem involvement. A CSFshunt was implanted in 2 patients before admission to our clinic and in one shortly after surgery. All but one patient received adjuvant treatment after surgery that consisted of combined chemoradiotherapy $(n=10)$, chemotherapy alone $(n=2)$ and radiotherapy alone $(n=2)$. Median overall survival (OS) for 14 patients was 50 months with 4 patients surviving for more than 100 
medRxiv preprint doi: https://doi.org/10.1101/2020.09.09.20188938; this version posted September 14 , 2020. The copyright holder for this preprint (which was not certified by peer review) is the author/funder, who has granted medRxiv a license to display the preprint in

All rights reserved. No reuse allowed without permission.

months, and being alive at the time of the preparation of this report. One patient dropped out of the follow-up because of moving to another country.

\section{Comparison with supratentorial anaplastic astrocytomas}

Characteristics of patients with cerebellar and supratentorial anaplastic astrocytomas are summarized in Table 2. Patients in the control group were matched in gender, age and IDH-1 mutation status with patients from the study group. Surprisingly, despite virtually ideal match, cerebellar AA had better outcome, than their supratentorial counterparts (OS: 50 months +/- 49.7 vs. $36.5+/-35.5$ months). However, analysis of Kaplan-Meyer survival curves showed no difference in survival rates (log-rank two-tailed test $\mathrm{p}=0.31)$.

To test for the effects of IDH-1 mutation on the survival outcomes we ran a Cox regression model with group clustering (see Methods) including IDH-1 status, gender, and age as covariates.

Age ad IDH-1 status came out significant predictors. While age has a negative effect on survival (increasing age by 1 year raises the hazard rate by $10.4 \%(\mathrm{p}<0.001)$ while presence of the positive IDH-1 mutation decreases the hazard rate by $32.1 \%(\mathrm{p}<0.001)$.

Table 1

\begin{tabular}{|l|l|l|l|l|l|l|}
\hline & coef. & $\exp ($ coef) & se(coef) & robust se & \multicolumn{1}{c|}{$z$} & $p$ \\
\hline Age & 0.0426 & 1.0435 & 0.0139 & 0.0124 & 3.42 & 0.00062 \\
\hline IDH1 & -0.3864 & 0.6795 & 0.4001 & 0.0907 & -4.26 & 0.0001 \\
\hline Gender & -0.3082 & 0.7347 & 0.3857 & 0.2975 & -1.04 & 0.30021 \\
\hline
\end{tabular}

(the full output for the model)

$n=60$, number of events $=28$

coef $\exp ($ coef) se(coef) robust se $z \operatorname{Pr}(>|z|)$
AGE
0.04257
1.04349
0.01245
3.4210 .000624
GENDER -0.30823
0.73475
$0.29752-1.0360 .300208$
IDH1
$-0.38639$
$0.67950 \quad 0.40011$
$0.09068-4.2612 .04 \mathrm{e}-05$
$\begin{array}{lrrrrr}\text { Signif. codes: } 0 \text { ‘**, } & 0.001 \text { ‘*, } & 0.01 ، *, & 0.05 \\ & & & & \\ \text { AGE } & 1.0435 & 0.9583 & 1.0183 & 1.0693 \\ \text { GENDER } & 0.7347 & 1.3610 & 0.4101 & 1.3164 \\ \text { IDH1 } & 0.6795 & 1.4717 & 0.5689 & 0.8117\end{array}$
Concordance $=0.661 \quad(\mathrm{se}=0.061)$
Rsquare $=0.157 \quad(\max$ possible $=0.964)$
Likelihood ratio test $=10.26$ on $3 \mathrm{df}, \quad p=0.0165$
Wald test $\quad=11.7$ on $3 \mathrm{df}, \quad p=0.008472$
Score (logrank) test $=11.12$ on $3 \mathrm{df}, \quad p=0.0111, \quad$ Robust $=2 \quad p=0.5724$ 
medRxiv preprint doi: https://doi.org/10.1101/2020.09.09.20188938; this version posted September 14,2020 . The copyright holder for this preprint (which was not certified by peer review) is the author/funder, who has granted medRxiv a license to display the preprint in

All rights reserved. No reuse allowed without permission.

We also looked at the effects of the MGMT-status in cAA group of patients only (since MGMT data were not available in the control group). MGMT-status had a marginal $(p=0.0916)$ significant negative effect on hazard rates when accounting for gender, age and IDH-1 status but more data are needed to conclude whether positive MGMT mutation might improve survival outcomes.

\section{Discussion}

A thorough literature review revealed just a few articles where "cerebellar anaplastic astrocytoma" term was mentioned, most of them published between 1990 to1998. Because of its' very limited number, we found it essential to considerate each of them.

Chamberlain et al. [4], described 18 "poorly differentiated gliomas of the cerebellum", but the sample included a series of glioblastomas (28\%), anaplastic astrocytomas (50\%) and "mixed gliomas" (22\%). Six patients were younger than 18 years old at diagnosis. Median survival rate for 9 cerebellar anaplastic astrocytomas (including 1 pediatric case) was 44 months. Interestingly, 5 out of 18 patients demonstrated tumour relapse: 3 leptomeningeal and 2 parenchymal extracerebellar (parietal lobe and upper cervical cord, respectively). Unfortunately, no information is given regarding the histological type of tumour with extracerebellar relapse.

Rizk et al. [22], also presented a mixed series of cerebellar glioblastomas $(n=2)$ and cerebellar anaplastic astrocytomas $(\mathrm{n}=8)$. This study was conducted in late 1970s - early 1990s and based on CT scan tumour appearances. Seventy percent of tumours developed within cerebellar vermis, $30 \%$ in hemispheres. Authors did not state median OS for either cGB or cAA, but 4 out of 8 cerebellar anaplastic astrocytomas were still alive by the time of article submitting without any signs of recurrence with a median follow-up of 7 years.

Paper of the most interest published by Djalilian et al. [7] presented an analytic review of malignant gliomas of the cerebellum and was based on 78 cases (37 cAA and $41 \mathrm{cGB}$ ), although only 7 of them were of authors' clinical experience. Median survival for patients with cAA was 32 months. Obvious conclusion is made that patients undergoing surgical resection and receiving radiation therapy demonstrated better survival rate. Despite the fact that the article combined both pediatric and adult cases, it provided a systematic review of malignant astrocytomas of the cerebellum revealing in particular 19 adult cAA patients (OS in this group was 53.8 months).

Since all those papers were published decades ago, no information regarding genetic profile of malignant cerebellar gliomas was reported.

In this study we presented a series of 15 consecutive adult patients with cerebellar anaplastic astrocytomas treated in a single institution for over 20-year period. Survival analyses was performed with respect to patients age and IDH-1 mutational status, as well as MGMT methylation 
medRxiv preprint doi: https://doi.org/10.1101/2020.09.09.20188938; this version posted September 14,2020 . The copyright holder for this preprint (which was not certified by peer review) is the author/funder, who has granted medRxiv a license to display the preprint in

All rights reserved. No reuse allowed without permission.

profile. We used control group of supratentorial AA as a "perfect match" with no difference in age, sex and IDH-1 mutation status.

Our results are aligned with previous studies demonstrating relatively prolonged survival in a group of cAA patients comparing to their supratentorial counterparts: in our group of cAA patients' OS was 50 months vs. 36.5 months in control group of supratentorial AA patients, but this difference did not reach statistical significance due to high variability in our sample. Median OS in a review published by Djalilian for 19 adult cAA patients was very similar - 32 months. [7] OS in our control group was similar to the data published before: Strowd et al. [26] demonstrated OS for AA in the temozolomide era as 36,7 months. For this comparison, it is noteworthy that both patients harboring additional supratentorial tumour (in case $1 \mathrm{AA}$, case 11 of unknown histology) had very short overall survival - 9 and 9.3 months, respectively. Probably, not only multiple location itself, but also a different tumour behavior could affect OS in those patients. Interestingly, the eldest patient in the group demonstrated 20-months OS despite the absence of any adjuvant treatment; he underwent repeated surgery after 12 months, but then deteriorated due to brainstem involvement by the tumour.

Rizk et al. [22], reported that 4 out of 8 cAA patients presented with more than 7 years of followup without sings of recurrent disease.

This higher survival rate of patients with cAA when comparing to supratentorial AA remains a puzzling phenomenon: malignant cerebellar tumors hypothetically should be associated with a heavier burden due to their fast expansion and building-up mass-effect in a small compartment of posterior fossa, containing critical life-supporting structures of the brainstem. Moreover, tumour may involve brainstem itself with catastrophic consequences. Despite all those well-recognized facts, cAA cases pertain a better prognosis than supratentorial tumours of the same histological type. It is also true for cerebellar glioblastomas: Yang et al. [33] presented a series of 28 cGB patients with OS 14.3 months. In a series of $202 \mathrm{cGB}$ collected from SEER database and presented by Babu et al. [2] OS both in cGB group and in supratentorial GB (sGB) group was similar (7 months). Multicenter study of cerebellar GBM conducted by Weber et al. [32] and based upon 45 cGB cases also suggested that prognosis of infratentorial GB was not different from supratentorial tumours with median OS of approximately 10 months. However, in all abovementioned series cGB groups were younger than sGB and that could have possibly affected OS rates. In our group age factor was carefully controlled by strict matching. No clear clarification of this phenomenon has been proposed so far.

One of the promising explanations - as well as for the rarity of malignant gliomas in the cerebellar - may be a substance P deficit in the cerebellar tissue. This amino acid peptide neurotransmitter is 
medRxiv preprint doi: https://doi.org/10.1101/2020.09.09.20188938; this version posted September 14, 2020. The copyright holder for this preprint (which was not certified by peer review) is the author/funder, who has granted medRxiv a license to display the preprint in

All rights reserved. No reuse allowed without permission.

active throughout the cerebrum and brainstem, but not in the cerebellum. Substance P signaling has been shown to play a contributory role in glioblastoma development. [11]

Quite an unexpected result of the present study is a very high incidence of IDH-1 mutations in the study cohort (40\%). In a similar study with 17 cerebellar GB conducted by Picart et al. [19] none of the reported tumours demonstrated IDH-1 positive status. It is a well-known fact that for supracerebellar gliomas IDH-1 mutation pertains better prognosis [6,13]. Overall, our results confirm this tendency for the whole cohort (study + control groups). Unfortunately, we failed to demonstrate it separately for cAA patients due to the group small sample size and it will need further investigation.

Our results also pointed towards a potentially promising role of methylated MGMT promoter status in influencing prolonged survival in cAA patients, but the effect remains marginal and will require future replications.

Finally, patients in the study group had more frequent multifocal presentation (13\% vs. $4.4 \%$ in the control group). One could argue that cerebellar affection is only a sign of the late stage of disease. To align with this assumption, both patients in the study group with multifocal gliomas demonstrated OS much lower than average ( 9 and 9.3 months, respectively, compared to 50 months).

Despite its limited sample-size and the absence of large-scale molecular analysis, the present study suggests that cAA do not correspond to a homogeneous entity but constitute a heterogeneous subgroup of anaplastic gliomas. We believe further accumulation of data for cAA with subsequent meta-analysis might shed light on cAA characteristics and possibly refine classification of these tumors. 
medRxiv preprint doi: https://doi.org/10.1101/2020.09.09.20188938; this version posted September 14 , 2020. The copyright holder for this preprint (which was not certified by peer review) is the author/funder, who has granted medRxiv a license to display the preprint in perpetuity.

All rights reserved. No reuse allowed without permission.

Table 2. Cerebellar anaplastic astrocytoma patients (global experience)

\begin{tabular}{|c|c|c|c|c|c|c|}
\hline \#\# & Author & $\begin{array}{c}\text { Year of } \\
\text { publication }\end{array}$ & Age & Sex & Treatment & OS, wks \\
\hline 1 & Budka [3] & 1975 & 41 & $\mathrm{~F}$ & STR & 1 \\
\hline 2 & Preissig [20] & 1979 & 52 & $M$ & STR, BCNU & 13 \\
\hline 3 & Salazar [23] & 1981 & 8 & $\mathrm{~F}$ & STR, PFI & 48 \\
\hline 4 & & & 6 & $\mathrm{~F}$ & STR, WBI & 52 \\
\hline 5 & & & 7 & $\mathrm{M}$ & STR, PFI & 45 \\
\hline 6 & & & 10 & $\mathrm{M}$ & STR, PFI & 87 \\
\hline 7 & & & 16 & $M$ & STR, SCl & 216 \\
\hline 8 & & & 13 & $\mathrm{M}$ & STR, SCl & 117 \\
\hline 9 & & & 10 & $\mathrm{M}$ & 2xSTR, SCl & 156 \\
\hline 10 & Alpers [1] & 1982 & 26 & $\mathrm{~F}$ & STR,RT,BCNU & 1 \\
\hline 11 & Kopelson [15] & 1982 & 15 & $M$ & $\mathrm{STR}, \mathrm{RT}$ & 459 \\
\hline 12 & & & 60 & $M$ & $\mathrm{RT}$ & 52 \\
\hline 13 & & & 30 & $\mathrm{M}$ & STR & 4 \\
\hline 14 & & & 67 & $\mathrm{M}$ & biopsy & 4 \\
\hline 15 & Zito [34] & 1983 & 77 & $\mathrm{~F}$ & STR,RT & 12 \\
\hline 16 & & & 85 & $\mathrm{M}$ & STR & 1 \\
\hline 17 & Steinberg [25] & 1985 & 15 & $\mathrm{M}$ & STR,PFI,BCNU,VCR & 30 \\
\hline 18 & & & 6 & $\mathrm{~F}$ & GTR,PFI & 182 \\
\hline 19 & Itoh [9] & 1988 & 1 & $\mathrm{~F}$ & STR & 1 \\
\hline 20 & Jaskolski [10] & 1988 & 52 & $\mathrm{~F}$ & 2xSTR, BCNU & 30 \\
\hline 21 & Shinoda [24] & 1989 & 12 & $\mathrm{~F}$ & $\mathrm{STR}, \mathrm{RT}$ & 26 \\
\hline 22 & & & 12 & $\mathrm{~F}$ & biopsy & 13 \\
\hline 23 & Chamberlain [4] & 1990 & 14 & $?$ & 2xSTR, PFI,ChT & 100 \\
\hline 24 & & & 21 & $?$ & 2xSTR, BCNU & 546 \\
\hline 25 & & & 44 & $?$ & STR,PFI,ChT & 221 \\
\hline 26 & & & 39 & $?$ & STR,PFI,ChT & 928 \\
\hline 27 & & & 25 & $?$ & 2xSTR, RT,ChT & 139 \\
\hline 28 & & & 33 & $?$ & STR,PFI,ChT & 26 \\
\hline 29 & & & 38 & $?$ & STR,PFI,ChT & 22 \\
\hline 30 & & & 29 & $?$ & 2xSTR, PFI,ChT & 169 \\
\hline 31 & & & 33 & $?$ & 2xSTR, PFI & 1568 \\
\hline 32 & Marchese [17] & 1990 & 11 & $?$ & STR, WBI & 115 \\
\hline 33 & Tsunoda [30] & 1992 & 44 & $\mathrm{M}$ & STR,WBI,PFI,ChT & 64 \\
\hline 34 & Djalilan [7] & 1996 & 63 & $\mathrm{~F}$ & STR, PFI & 12 \\
\hline 35 & Walid [31] & 2008 & 14 & $\mathrm{M}$ & STR,ChT & $>25$ \\
\hline 36 & Morgan [18] & 2016 & 47 & $M$ & 2xSTR, RT,ChT & $>92$ \\
\hline 37 & Kozhuki [14] & 2018 & 75 & $\mathrm{M}$ & STR, RT,ChT & $>105$ \\
\hline $38-45$ & Rizk [22] & 1994 & 8 patients & & & \\
\hline
\end{tabular}

Abbreviations: STR - subtotal resection, GTR - gross total resection, PFI - posterior fossa irradiation, $\mathrm{WBI}$ - whole brain irradiation, RT - radiotherapy, ChT - chemotherapy; $\mathrm{BCNU}$ carmustine, VCR - vincristine. 
medRxiv preprint doi: https://doi.org/10.1101/2020.09.09.20188938; this version posted September 14 , 2020. The copyright holder for this preprint (which was not certified by peer review) is the author/funder, who has granted medRxiv a license to display the preprint in perpetuity.

All rights reserved. No reuse allowed without permission.

Table 3. Patients' characteristics

\begin{tabular}{|c|c|c|c|c|c|c|c|c|c|c|}
\hline Patients & $\begin{array}{c}\text { Personal } \\
\text { History }\end{array}$ & Sex & Age & $\begin{array}{l}\text { Tumor } \\
\text { Location }\end{array}$ & $\begin{array}{c}\text { Supratentorial } \\
\text { Tumor }\end{array}$ & Surgery & $\begin{array}{c}\text { IDH-1 } \\
\text { Mutaion }\end{array}$ & $\begin{array}{c}\text { MGMT } \\
\text { methylation }\end{array}$ & $\begin{array}{l}\text { Adjuvant } \\
\text { treatment }\end{array}$ & $\begin{array}{c}\text { OS } \\
\text { (mounth) }\end{array}$ \\
\hline 1 & No & $M$ & $25-30$ & $\mathrm{H}, \mathrm{V}$ & $\begin{array}{c}\text { left frontal lobe } \\
+\mathrm{CC}\end{array}$ & GTR,S & + & - & $C, R$ & 9 \\
\hline 2 & No & $\mathrm{M}$ & $37-43$ & $\mathrm{H}, \mathrm{V}$ & No & $B, S$ & - & - & $\mathrm{C}$ & 48,9 \\
\hline 3 & No & $F$ & $29-33$ & $\mathrm{H}, \mathrm{V}$ & No & GTR & - & - & $R$ & 5,4 \\
\hline 4 & No & $\mathrm{F}$ & $45-50$ & $\mathrm{H}$ & No & GTR & + & + & $C, R$ & 110,6 alive \\
\hline 5 & No & $\mathrm{F}$ & $52-56$ & $\mathrm{H}, \mathrm{V}$ & No & STR,S & + & + & $C, R$ & 6,3 \\
\hline 6 & No & $\mathrm{M}$ & $40-45$ & $\mathrm{~V}$ & No & GTR & - & - & $R$ & 8,1 \\
\hline 7 & No & M & $70-75$ & $\begin{array}{c}1-\mathrm{H} \\
2-\mathrm{H}, \mathrm{V}, \mathrm{BrSt} \\
\end{array}$ & No & $\begin{array}{c}\text { 1-GTR 2- } \\
\text { STR }\end{array}$ & - & - & No & 20 \\
\hline 8 & No & $M$ & $19-23$ & $\mathrm{~V}$ & No & GTR,S & + & - & $C, R$ & 100,4 alive \\
\hline 9 & No & $\mathrm{F}$ & $56-60$ & $\mathrm{H}$ & No & GTR & - & + & $C, R$ & 7,4 \\
\hline 10 & Cr uteri & $\mathrm{F}$ & $49-53$ & $\mathrm{H}, \mathrm{V}$ & No & GTR & - & + & $C, R$ & 62,7 \\
\hline 11 & No & $\mathrm{F}$ & $38-42$ & $\mathrm{H}$ & $\begin{array}{c}\text { right parietal } \\
\text { lobe }\end{array}$ & GTR & + & - & $C, R$ & 9,3 \\
\hline 12 & No & $\mathrm{M}$ & $19-23$ & $\mathrm{~V}$ & No & STR & + & $?$ & $\mathrm{C}, \mathrm{R}$ & 159 alive \\
\hline 13 & No & $\mathrm{M}$ & $17-21$ & $\mathrm{H}$ & No & GTR & - & - & $\mathrm{C}$ & 30,8 \\
\hline 14 & No & $\mathrm{M}$ & $44-48$ & $\mathrm{~V}$ & No & GTR & - & + & $\mathrm{C}, \mathrm{R}$ & $? ?$ \\
\hline 15 & NF-1 & $\mathrm{F}$ & $20-24$ & $\mathrm{H}, \mathrm{V}$ & No & STR & - & - & $C, R$ & 121,8 alive \\
\hline
\end{tabular}

Abbreviations: NF-1 - neurofibromatosis type I; H - cerebellar hemisphere; V - cerebellar vermis; $\mathrm{BrSt}$ brainstem; CC - corpus callosum; GTR - gross total resection; STR - subtotal resection; B - tumour biopsy; $\mathrm{S}$ - shunt placement; $\mathrm{C}$ - chemotherapy; $\mathrm{R}$ - radiotherapy; OS - overall survival.

Figure 1. Patient 45-49 years, pre-op MRI

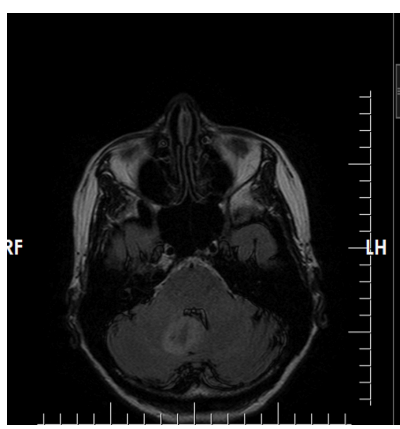

FLAIR

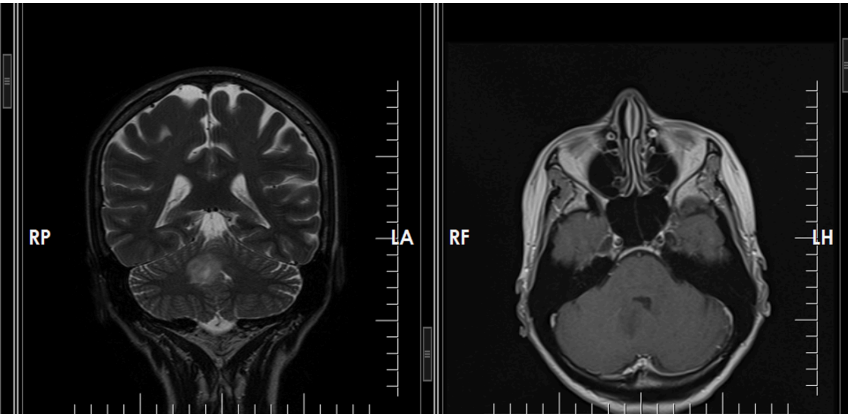

$\mathrm{T} 2 \mathrm{WI}$

$\mathrm{T} 1+\mathrm{C}$

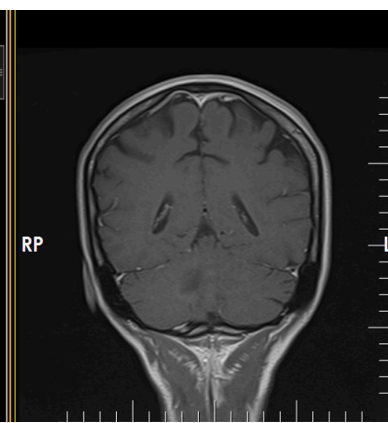

$\mathrm{T} 1+\mathrm{C}$ 


\section{REFERENCES}

1. Alpers, C. E., Davis, R. L., \& Wilson, C. B. (1982). Persistence and late malignant transformation of childhood cerebellar astrocytoma. Case report. Journal of Neurosurgery, 57(4), 548-551. https://doi.org/10.3171/jns.1982.57.4.0548

2. Babu, R., Sharma, R., Karikari, I. O., Owens, T. R., Friedman, A. H., \& Adamson, C. (2013). Outcome and prognostic factors in adult cerebellar glioblastoma. Journal of Clinical Neuroscience, 20(8), 1117-1121. https://doi.org/10.1016/j.jocn.2012.12.006]

3. Budka, H. (1975). Partially resected und irradiated cerebellar astrocytoma of childhood: Malignant evolution after 28 years. Acta Neurochirurgica, 32(1-2), 139-146. https://doi.org/10.1007/BF01405911

4. Chamberlain, M. C., Silver, P., \& Levin, V. A. (1990). Poorly differentiated gliomas of the cerebellum. A study of 18 patients. Cancer, 65(2), 337-340. https://doi.org/10.1002/10970142(19900115)65:2<337::AID-CNCR2820650226>3.0.CO;2-P],

5. Cho, H. J., Zhao, J., Jung, S. W., Ladewig, E., Kong, D. S., Suh, Y. L., Lee, Y., Kim, D., Ahn, S. H., Bordyuh, M., Kang, H. J., Sa, J. K., Seo, Y. J., Kim, S. T., Lim, D. H., Dho, Y. S., Lee, J. Il, Seol, H. J., Choi, J. W., ... Nam, D. H. (2019). Distinct genomic profile and specific targeted drug responses in adult cerebellar glioblastoma. Neuro-Oncology, 21(1), 47-58. https://doi.org/10.1093/neuonc/noy123],

6. Christians, A., Adel-Horowski, A., Banan, R., Lehmann, U., Bartels, S., Behling, F., Barrantes-Freer, A., Stadelmann, C., Rohde, V., Stockhammer, F., \& Hartmann, C. (2019). The prognostic role of IDH mutations in homogeneously treated patients with anaplastic astrocytomas and glioblastomas. Acta Neuropathologica Communications, 7(1). https://doi.org/10.1186/s40478-019-0817-0

7. Djalilian, H. R., \& Hall, W. A. (1998). Malignant gliomas of the cerebellum: An analytic review. Journal of Neuro-Oncology, 36(3), 247-257. https://doi.org/10.1023/A:1005704006244]

8. Hong, B., Banan, R., Christians, A., Nakamura, M., Lalk, M., Lehmann, U., Hartmann, C., \& Krauss, J. K. (2018). Cerebellar glioblastoma: a clinical series with contemporary molecular analysis. Acta Neurochirurgica. https://doi.org/10.1007/s00701-018-3673-y].

9. Itoh, Y., Kowada, M., Mineura, K., Kojima, H., \& Sageshima, M. (1988). Primary malignant astrocytoma of the cerebellum in children - Report of a case with electron microscopic and cytofluorometric DNA evaluation. Child's Nervous System, 4(5), 306-309. https://doi.org/10.1007/BF00271931

10. Jaskolski, D., Zawirski, M., Wisniewska, G., \& Papierz, W. (1988). A case of multicentric glioma of cerebellum and brain. Zentralblatt Fur Neurochirurgie, 49(2), 124-127.

11.Kast, R. E. (2009). Why cerebellar glioblastoma is rare and how that indicates adjunctive use of the fda-approved anti-emetic aprepitant might retard cerebral glioblastoma growth: A new hypothesis to an old question. Clinical and Translational Oncology, 11(7), 408-410. https://doi.org/10.1007/s12094-009-0379-x], 
medRxiv preprint doi: https://doi.org/10.1101/2020.09.09.20188938; this version posted September 14, 2020. The copyright holder for this preprint (which was not certified by peer review) is the author/funder, who has granted medRxiv a license to display the preprint in

12. Kawase, T., Nakamura, T., Kanno, T., \& Nakazato, Y. (1993). Anaplastic astrocytoma in the cerebellopontine angle. Nōshuyō Byōri = Brain Tumor Pathology, 10(1), 53-56.]

13. Kizilbash, S. H., Giannini, C., Voss, J. S., Decker, P. A., Jenkins, R. B., Hardie, J., Laack, N. N., Parney, I. F., Uhm, J. H., \& Buckner, J. C. (2014). The impact of concurrent temozolomide with adjuvant radiation and IDH mutation status among patients with anaplastic astrocytoma. Journal of Neuro-Oncology, 120(1), 85-93. https://doi.org/10.1007/s11060-014-1520-4

14. Kohzuki, H., Matsuda, M., Miki, S., Shibuya, M., Ishikawa, E., \& Matsumura, A. (2018). Diffusely Infiltrating Cerebellar Anaplastic Astrocytoma Effectively Controlled with Bevacizumab: Case Report and Literature Review. World Neurosurgery, 115, 181-185. https://doi.org/10.1016/j.wneu.2018.04.110],

15. Kopelson, G. (1982). Cerebellar glioblastoma. Cancer, 50(2), 308-311. https://doi.org/10.1002/1097-0142(19820715)50:2<308::AID-CNCR2820500224>3.0.CO;2-L

16. Levine SA, McKeever PE, Greenberg HS. Primary cerebellar glioblastoma multiforme. J Neurooncol. 1987;5(3):231-236. doi:10.1007/BF00151226

17. Marchese, M. J., \& Chang, C. H. (1990). Malignant astrocytic gliomas in children. Cancer, 65(12), 2771-2778. https://doi.org/10.1002/1097-0142(19900615)65:12<2771::AIDCNCR2820651227>3.0.CO;2-J

18. Morgan H., McDonald M., Wilkinson J. (2016). Subclinical recurrence of anaplastic astrocytoma: Demonstrating the difficulty in distinguishing progression from pseudoprogression. Applied Radiation Oncology, Sep 2016, 32-35.],

19. Picart, T., Barritault, M., Berthillier, J., Meyronet, D., Vasiljevic, A., Frappaz, D., Honnorat, J., Jouanneau, E., Poncet, D., Ducray, F., \& Guyotat, J. (2018). Characteristics of cerebellar glioblastomas in adults. Journal of Neuro-Oncology, 136(3), 555-563. https://doi.org/10.1007/s11060-017-2682-7].

20. Preissig, S. H., Bohmfalk, G. L., Reichel, G. W., \& Smith, M. T. (1979). Anaplastic astrocytoma following radiation for a glomus jugulare tumor. Cancer, 43(6), 2243-2247. https://doi.org/10.1002/1097-0142(197906)43:6<2243::AID-CNCR2820430614>3.0.CO;2-K

21. Reinhardt, A., Stichel, D., Schrimpf, D., Koelsche, C., Wefers, A. K., Ebrahimi, A., Sievers, P., Huang, K., Casalini, M. B., Fernández-Klett, F., Suwala, A., Weller, M., Gramatzki, D., Felsberg, J., Reifenberger, G., Becker, A., Hans, V. H., Prinz, M., Staszewski, O., ... Von Deimling, A. (2019). Tumors diagnosed as cerebellar glioblastoma comprise distinct molecular entities. Acta Neuropathologica Communications, 7(1). https://doi.org/10.1186/s40478-0190801-8],

22. Rizk, T., Remond, J., Alhayek, G., Fournier, D., Menei, P., Mercier, P., \& Guy, G. (1994). Malignant astrocytoma of the cerebellum. Apropos of 10 cases. Review of the literature. NeuroChirurgie, 40(2), 121-126.],

23. Salazar, O. M. (1981). Primary malignant cerebellar astrocytomas in children: A signal for postoperative craniospinal irradiation. International Journal of Radiation Oncology, Biology, Physics, 7(12), 1661-1665. https://doi.org/10.1016/0360-3016(81)90189-9], 
medRxiv preprint doi: https://doi.org/10.1101/2020.09.09.20188938; this version posted September 14, 2020. The copyright holder for this preprint (which was not certified by peer review) is the author/funder, who has granted medRxiv a license to display the preprint in

All rights reserved. No reuse allowed without permission.

24. Shinoda, J., Yamada, H., Sakai, N., Ando, T., Hirata, T., \& Hirayama, H. (1989). Malignant cerebellar astrocytic tumours in children. Acta Neurochirurgica, 98(1-2), 1-8. https://doi.org/10.1007/BF01407169],

25. Steinberg, G. K., Shuer, L. M., Conley, F. K., \& Hanbery, J. W. (1985). Evolution and outcome in malignant astroglial neoplasms of the cerebellum. Journal of Neurosurgery, 62(1), 9-17. https://doi.org/10.3171/jns.1985.62.1.0009],

26. Strowd RE, Abuali I, Ye X, Lu Y, Grossman SA. The role of temozolomide in the management of patients with newly diagnosed anaplastic astrocytoma: a comparison of survival in the era prior to and following the availability of temozolomide. J Neurooncol.

2016;127(1):165-171. doi:10.1007/s11060-015-2028-2]

27. Terry M. Therneau and Patricia M. Grambsch (2000). Modeling Survival Data: Extending the Cox Model. Springer, New York. ISBN 0-387-98784-3.)

28. Therneau $\mathrm{T}$ (2015). A Package for Survival Analysis in S_. version 2.38, $<$ URL:https://CRAN.R-project.org/package $=$ survival $>$.

29. Therneau, T., Grambsch, P., Modeling Survival Data: Extending the Cox Model. SpringerVerlag, 2000).

30. Tsunoda, S., Sakaki, T., Goda, K., Nakamura, M., Hashimoto, H., Hoshida, T., Morimoto, T., \& Kubota, T. (1992). Anaplastic Astrocytoma of an Oncocytic Type Occurringin the Cerebellar Vermis in Pierre Robin Syndrome Report. Neurologia Medico-Chirurgica, 32(12), 911-914. https://doi.org/10.2176/nmc.32.911].

31. Walid, M. S., \& Troup, E. C. (2008). Cerebellar anaplastic astrocytoma in a teenager with Ollier Disease. Journal of Neuro-Oncology, 89(1), 59-62. https://doi.org/10.1007/s11060-0089583-8],

32. Weber, D. C., Miller, R. C., Villà, S., Hanssens, P., Baumert, B. G., Castadot, P., Varlet, P., Abacioglu, U., Igdem, S., Szutowicz, E., Nishioka, H., Hofer, S., Rutz, H. P., Ozsahin, M., Taghian, A., \& Mirimanoff, R. O. (2006). Outcome and prognostic factors in cerebellar glioblastoma multiforme in adults: A retrospective study from the Rare Cancer Network. International Journal of Radiation Oncology Biology Physics, 66(1), 179-186.

https://doi.org/10.1016/j.ijrobp.2006.04.035]

33. Yang, S., Liu, J., Wang, T., Li, X., \& You, C. (2013). Cerebellar glioblastoma multiforme: A retrospective study of 28 patients at a single institution. International Journal of Neuroscience. https://doi.org/10.3109/00207454.2013.791292]

34. Zito, J. L., Siva, A., Smith, T. W., Leeds, M., \& Davidson, R. (1983). Glioblastoma of the cerebellum. Computed tomographic and pathologic considerations. Surgical Neurology, 19(4), 373-378. https://doi.org/10.1016/0090-3019(83)90248-3 